\title{
MYOSTATIN COORDINATING THE PROLIFERATION AND DIFFERENTIATION OF ADIPOSE AND SKELETAL MUSCLE CELLS AND ENERGY METABOLISM BALANCE BASED ON GENE CHIP TECHNOLOGY
}

\author{
AMIOSTATINA NA COORDENAÇÃO DA PROLIFERAÇÃO EDIFERENCIAÇÃO DE CÉLULAS MUSCULARES \\ ADIPOSASE ESQUELÉTICASENO EQUILIBBRIO DO METABOLISMO ENERGÉTICOCOM BASENA \\ TECNOLOGIA DECHIPS GENÉTICOS
}
MSRN, BASADO EN LA TECNOLOGÍA DE CHIPS GENÉTICOS, COORDINA LA FERTILIZACIÓN Y EL METABOLISMO DE LAS CÉLULAS MUSCULARES GRASAS YÓSEAS

Qijun Ren' (ID
(Public Health)
Rihua Cong'
(Basic Medicine)

1. School of Physical Education, Northwest A\&F University, Yangling 712100, Shaanxi, China.

\section{Correspondence:}

Yangling 712100, Shaanxi, China. gv43790@21cn.com px942608@21cn.com

\begin{abstract}
Myoblasts fuse into multinucleated muscle fibers to form and promote the growth of skeletal muscle. In order to analyze the role of myostatin (MSTN) in body fat, skeletal muscle cell proliferation and differentiation and energy metabolism, this study will use the antisense RNA technology of gene chip technology to study it. The results showed that the MSTN gene regulated the growth and proliferation of myoblasts and affected the development of skeletal muscle by affecting the expression of Cdc42, bnip2, p38 and other genes; knockout or overexpression of the MSTN gene would lead to a trend of fat-related genes from fat synthesis to fat decomposition; after the MSTN gene was knocked down, the expression levels of cpti-b, PPARG and other genes in the cells were corresponding after MSTN overexpression, the relative expression of the PPARG gene decreased. It is suggested that the knockout or overexpression of MSTN may affect lipid accumulation, and cpti-b and PPARG may directly regulate lipid level. It is hoped that this experiment can provide a reference for the study of MSTN effect on fat deposition.
\end{abstract}

Keywords: RNA, Antisense; Myostatin;" Metabolism; Myoblasts.

\section{RESUMO}

Os mioblastos se fundem eM fibras musculares multinucleadas para formar e promover o crescimento do músculo esquelético. A fim de analisar o papel da miostatina (MSTN) na gordura corporal, proliferação de células musculares esqueléticas e diferenciação e metabolismo energético, este estudo utilizará a tecnologia anti-RNA de chips genéticos para estudá-la. Os resultados mostraram que o gene MSTN regulava o crescimento e a proliferação de mioblastos e afetava o desenvolvimento do músculo esquelético, afetando a expressão de Cdc42, bnip2, p38 e outros genes; a eliminação ou sobrexpressão do gene MSTN conduziria a uma ten dência de os genes adiposos sintetizarem a gordura até sua decomposição; após a eliminação do gene MSTN, os níveis de expressão de cpti-b, PPARG e outros genes nas células mostraram-se correspondentes após a sobrexpressão do gene MSTN, e a expressão relativa do genePPARG diminuiu. Sugere-se que a eliminação ou sobrexpressão da MSTN possa afetar a acumulação de lipídeos, e o cpti-b e o PPARG podem regular diretamente o nível lipídico. Espera-se que esta experiência possa fornecer uma referência para o estudo do efeito da MSTN sobre a deposição de gordura.

Descritores: RNA Antissenso; Miostatina; Metabolismo; Miooblastos.

\section{RESUMEN}

Los mioblastos se funden en fibras musculares multinucleadas para formary promover el crecimiento del músculo esquelético. A fin de analizar el papel de la miostatina (MSTN) en la grasa corporal, proliferación de células musculares esqueléticas y diferenciación y metabolismo energético, este estudio utilizará la tecnología anti-RNA de chips genéticos para estudiarla. Los resultados mostraron que el gen MSTN regulaba el crecimiento y la proliferación de mioblastos y afectaba el desarrollo del músculo esquelético, afectando la expresión de Cdc42, bnip2, p38y otros genes; la eliminación o sobreexpresión del gen MSTN conduciría a una tendencia de que los genes adiposos sinteticen la grasa hasta su descomposición; después de la eliminación del gen MSTN, los niveles de expresión de cpti-b, PPARG y otros genes en las células se mostraron correspondientes después de la sobreexpresión del gen MSTN, y la expresión relativa del gen PPARG disminuyó. Se sugiere que la eliminación o sobreexpresión de la MSTN pueda afectar la acumulación de lipídos, y el cpti-b y el PPARG pueden regular directamente el nivel lipídico. Se espera que esta experiencia pueda proveer una referencia para el estudio del efecto de la MSTN sobre el depósito de grasa.

Descriptores: RNA Antisentido; Miostatina;: Metabolismo; Mioblastos. 


\section{INTRODUCTION}

With the development of gene chip technology, the research on various physiological activities of the body is gradually transferred to the gene level. Previous studies have shown that myostatin (MSTN) knockout will lead to the increase of muscle mass and the decrease of fat content. The formation and growth of skeletal muscle need the fusion of myoblasts. Myoblasts are undifferentiated muscle precursor cells. The fusion of myoblasts can increase the number of nuclei in muscle fiber cytoplasm, increase the cytoplasm regulated by nucleus, and increase the volume of muscle cells. In order to analyze the role of MSTN in coordinating the proliferation and differentiation of adipose and skeletal muscle cells and the balance of energy metabolism, this study will use the antisense RNA technology of gene chip technology to construct the bidirectional expression vector pmstn CMV CAG antimstn, and transfect bovine muscle satellite cells with rnai926 interference vector, anti MSTN vector and over expression MSTN vector To find out the actual effect of MSTN on the expression of fat related genes, find out the related genes affecting fat metabolism, and then study the coordination of MSTN on energy metabolism. The proliferation and differentiation of skeletal muscle cells are affected by myoblasts. Since the signal molecules in the regulation of skeletal muscle cell differentiation by cell growth factors are not clear, we will indirectly analyze the effect of MSTN on the proliferation and differentiation of skeletal muscle cells through the study of MSTN on the growth, proliferation and differentiation of myoblasts.

In this study, we used the antisense RNA technology of gene chip technology to construct the bidirectional expression vector pmstn CMV CAG anti MSTN, and screened the best inhibition vector by Western blot, which can be used as MSTN antisense vector. Antisense RNA refers to a single stranded RNA molecule that can complement the mRNA of target gene or DNA of target gene. After binding to target gene, it forms stable double strand, thus inhibiting the expression of the gene and playing the role of regulating gene.

The innovation of this study lies in the application of antisense RNA technology in fat related research of livestock and large animals (cattle). Without affecting the normal expression of other genes, targeted inhibition of multiple gene expression under the target promoter reduces the problems existing in conventional genetic analysis. The inhibition effect of antisense RNA technology is targeted, selective and efficient. At the same time, antisense RNA technology does not have the ability of translation, can not produce protein, does not damage the structure of endogenous gene, and has high security.

\section{RELATED WORK}

When studying the role of gene regulation in neuronal damage induced by ischemic stroke, Pulliam JVK et al. Used gene chip technology to analyze the changes of gene transcription in rat brain tissue after ischemia-reperfusion, and identified ischemia-induced genes through conservative transcription factor binding sites, so as to carry out relevant research on the mechanism of brain injury.' Li C and other researchers have developed a microarray based on flow field hybridization gene chip technology, which can identify Candida famale and highly related Candida species with strong identification performance. ${ }^{2} \mathrm{~Gy}$ Han and other scholars used genetic deafness gene chip technology to detect deafness related mutation sites. The results show that the technology can detect deafness related mutation sites quickly and fluently, and fully meet the needs of clinical deaf gene detection. ${ }^{3}$ Fan DJ and his team detected the relationship between acute cerebral infarction and CYP2C19 gene polymorphism through gene chip technology. The experimental results showed that CYP2C19 gene polymorphism may lead to increased risk of cerebral infarction in the elderly. ${ }^{4} \mathrm{Gu}$ Hao et al. Found that somatostatin MSTN can regulate the number of skeletal muscle cells, and MSTN has myogenic regulatory function, which can affect the development and metabolism of adipose tissue. 5 Susannah Wright and her team introduced myostatin mutation into inbred mice, and found that the muscle weight of mice increased significantly, the weight of organs and fat decreased, and the body fat ratio decreased. ${ }^{6}$ Kang J D and other scholars constructed a pair of activator of transcription like effect nuclease pairs of pig MSTN gene exon 1, and transfected them into porcine fetal fibroblasts, and used them as donors to produce cloned pigs. The results showed that these pigs showed high muscle characteristics. ${ }^{7}$ Chen R and other researchers found that betaine can linearly down regulate the expression of Somatostatin mRNA and improve the antioxidant activity of muscle. ${ }^{8}$

To sum up, there are many studies on gene chip technology, MSTN on proliferation and differentiation of adipose and skeletal muscle cells, MSTN on energy metabolism balance, but there is no experiment to combine the three. Objective to study the role of MSTN in coordinating the proliferation, differentiation and energy conservation of adipose and skeletal muscle cells by microarray technology.

\section{Experimental design and analysis}

The lentiviral vector pcd513b CMV and the amplified gene sequence were digested by double enzyme digestion and ligation reaction. Positive bacterial clones were selected and identified by colony PCR. Myoblast was transfected by recombinant lentivirus pcd513b CMV FST. The transfection results are shown in Figure 1.

The results showed that the expression of fst- 6 gene in the control group increased with the time of transfection. Figure (b) shows the expression of fluorescent protein under different concentration gradients of lentivirus. It can be found that when the concentration of lentivirus is $10-2 \mu \mathrm{L}$, the expression of green fluorescent protein is the most obvious, that is, the transfection efficiency is the highest. According to the expression efficiency of green fluorescent protein (GFP) in myoblasts in figure (c), the MOI value was between 10-50, and the infection efficiency showed that the fluorescence cells in the myoblasts infected by lentivirus were more than $90 \%$. The expression of bnip42 (cell growth inhibition), cell division cycle 42 (Cdc42), myogenic differentiation antigen (MyoD), myogenin and MSTN were detected in infected myoblasts.

It can be seen from figure $2(a, b)$ that the expression levels of bnip42, Cdc42, MyoD, myogenin, MSTN, etc. in myoblasts infected with pcd513b cmv-fst showed obvious changes, indicating that MSTN had an effect on the production of myoblasts; figure (c) showed that the expression of Cdc42, bnip2 and p38 genes in the cell line increased after MSTN gene was knocked out; Figure (e) showed that p38MAPK signal transduction was added The expression of related proteins in FST overexpression cell line mediated by lentivirus is shown in Figure (d). These results indicate that inhibition of MSTN gene expression or direct knockout of MSTN gene can increase the expression of Cdc42 (regulating cell division cycle), bnip2 (controlling cell growth and inhibiting cell growth) and p38 gene expression, thus regulating the development of skeletal muscle.

The ${ }^{\prime * * *}$ "in Figure 3 shows that there are significant differences $(P<$ $0.05)$ and extremely significant differences $(P<0.01)$ between the two groups;" NC "refers to" normal control ", which means untreated cells in the control group; and" anti-mstn3 "refers to the cells transfected with antisense mstn3. According to Fig. 8a, FASN (2.29, The expression of cpti-b $(4.68, \mathrm{P}<0.01)$ and acox-1 $(1.66, \mathrm{P}<0.01)$ related to fatty acid oxidation increased, while the expression of echdc1 $(0.83, P<0.05)$ decreased The expression of PPARG $(2.26, P<0.01)$ and lip $(2.05, P<0.01)$ was increased, and the expression of LPL $(0.79, P<0.01)$ was decreased, and there were significant differences in the expression levels of the three genes; figure D showed that the expression of FATP $(1.04, \mathrm{P}>0.05)$ was unchanged in fat transport genes The expression of MSTN $(0.23, P<0.01)$ decreased after transfection of antisense fragment m3. On the whole, lipid oxidative decomposition (12.27) was stronger than fat synthesis (5.77). After transfection with rnai926 interference vector, the changes of mRNA levels of various genes related to fat are shown in Figure 4. 


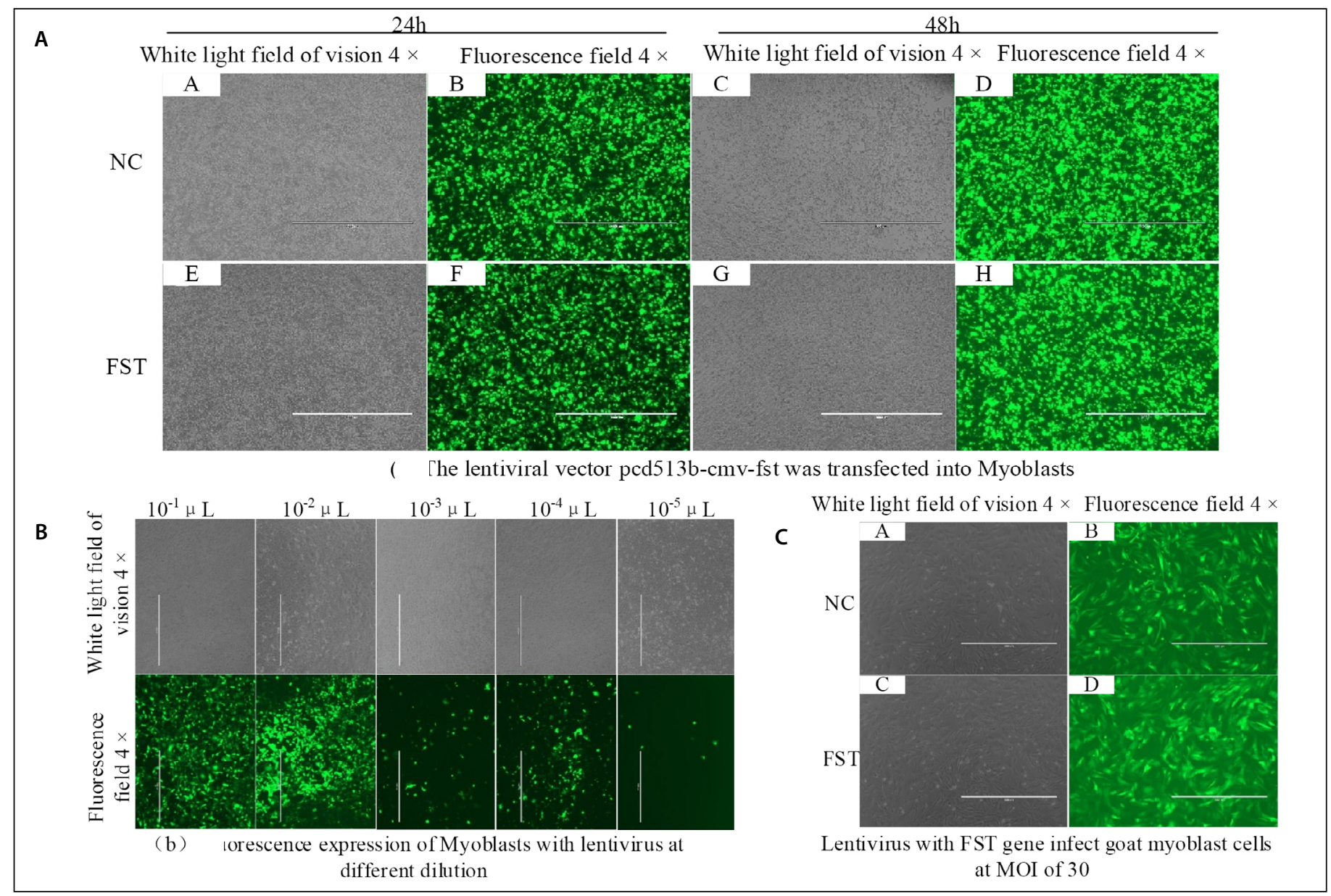

Figure 1. Infection and transfection effect of chronic virus on myoblasts.

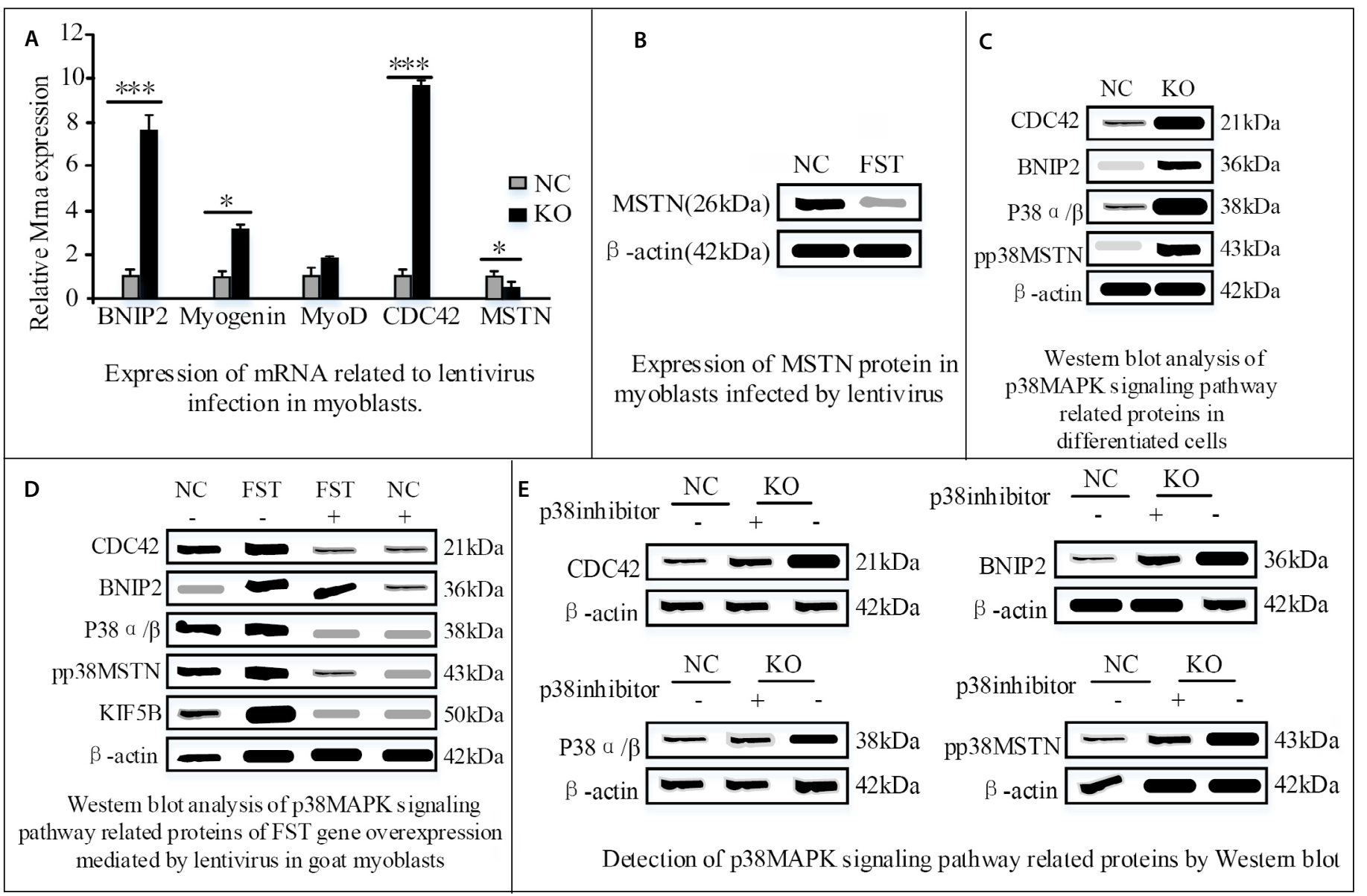

Figure 2. The role of MSTN in the proliferation and differentiation of skeletal muscle cells(FST: FST over expression group; NC: control group; KO: MSTN KO group). 


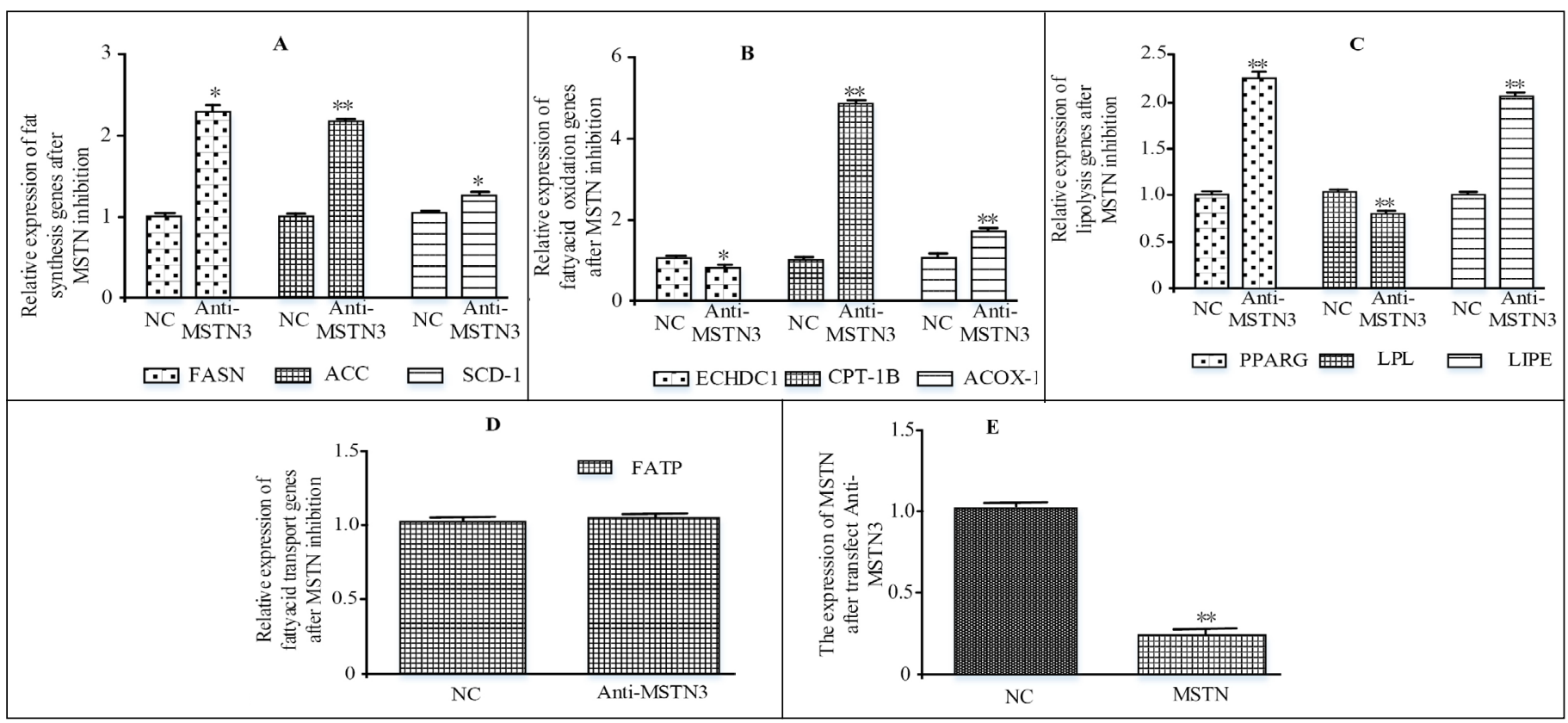

Figure 3. Expression of fat related genes in bovine muscle satellite cells after MSTN expression was inhibited by antisense RNA.

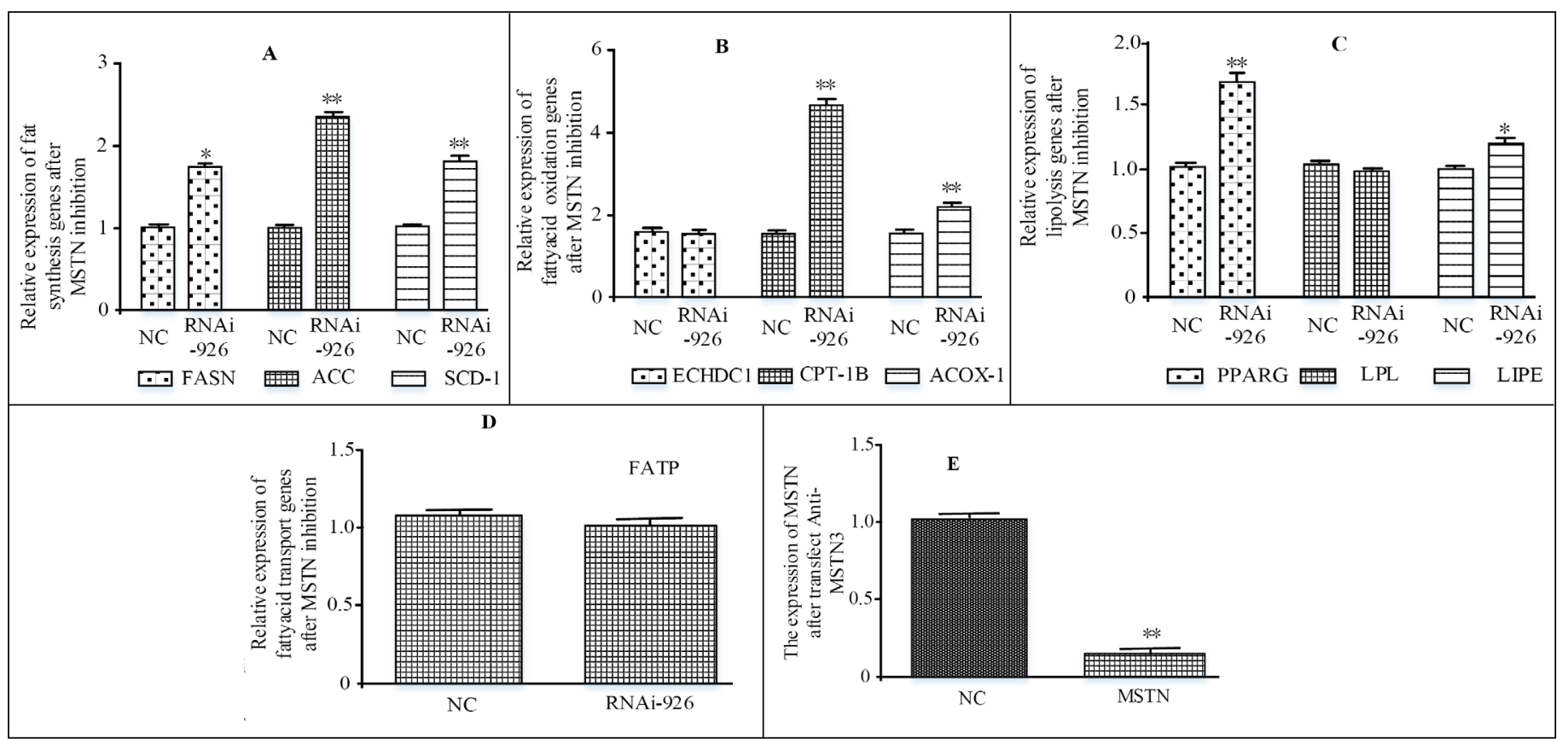

Figure 4. Expression of fat related genes in bovine muscle satellite cells after MSTN expression was inhibited by RNA interference.

"Rnai-926" in Figure 4 refers to the cells transfected with rnai926 interference vector. Compared with the control group, the expression levels of FASN, ACC and scd-1 in adipose synthesis related genes are increased, with significant difference; figure B shows that the expression levels of gene cpti-b and acox-1 in fatty acid oxidation related genes are significantly increased, while the expression of gene echdc1 does not change significantly Figure $C$ showed that PPARG and lip increased significantly, but LPL had no significant difference; Figure D showed no significant change in fat transport genes; Figure e showed that the expression of MSTN decreased significantly after rnai926 transfection. On the whole, the oxidative decomposition degree of fat (8.66) was stronger than that of fat synthesis (5.95).

In Figure 5, "MSTN +" refers to the cells transfected with MSTN overexpression vector. Compared with the control group, the expression levels of FASN $(1.37, P<0.01)$ and ACC $(1.76, P<0.01)$ in fat synthesis genes shown in Fig. a were significantly increased, while the expression of scd-1 (0.95, P<0.05) was significantly decreased; in Fig. B, cpti-b (2.99, $P<0.01)$ was shown in fatty acid oxidation related genes The results showed that the expression levels of gene PPARG $(0.79, P<0.05)$ were significantly decreased, the expression of lip (1.09, P<0.05) and LPL (1.20, $P<0.01)$ were significantly increased; there was no significant change in fat transport genes in Figure D; there was no significant change in fat transport genes in Figure D; there was no significant change in Figure EThe expression of MSTN $(2.28, \mathrm{P}<0.05)$ increased significantly after transfection with MSTN overexpression vector. On the whole, the oxidative decomposition degree of fat (8.65) was stronger than that of fat synthesis (4.08). After MSTN knockout, the mRNA levels of fat related genes changed as shown in figure 6.

In Figure 6, "MSTN (- / -) mice" refers to the muscle tissue of MSTN knockout mice, and "wild type" refers to the muscle tissue of wild type mice. Compared with the control group, the expressions of FASN (23.72, $P<0.01)$ and scd-1 $(7.64, P<0.01)$ in fat synthesis genes shown in Fig. a 


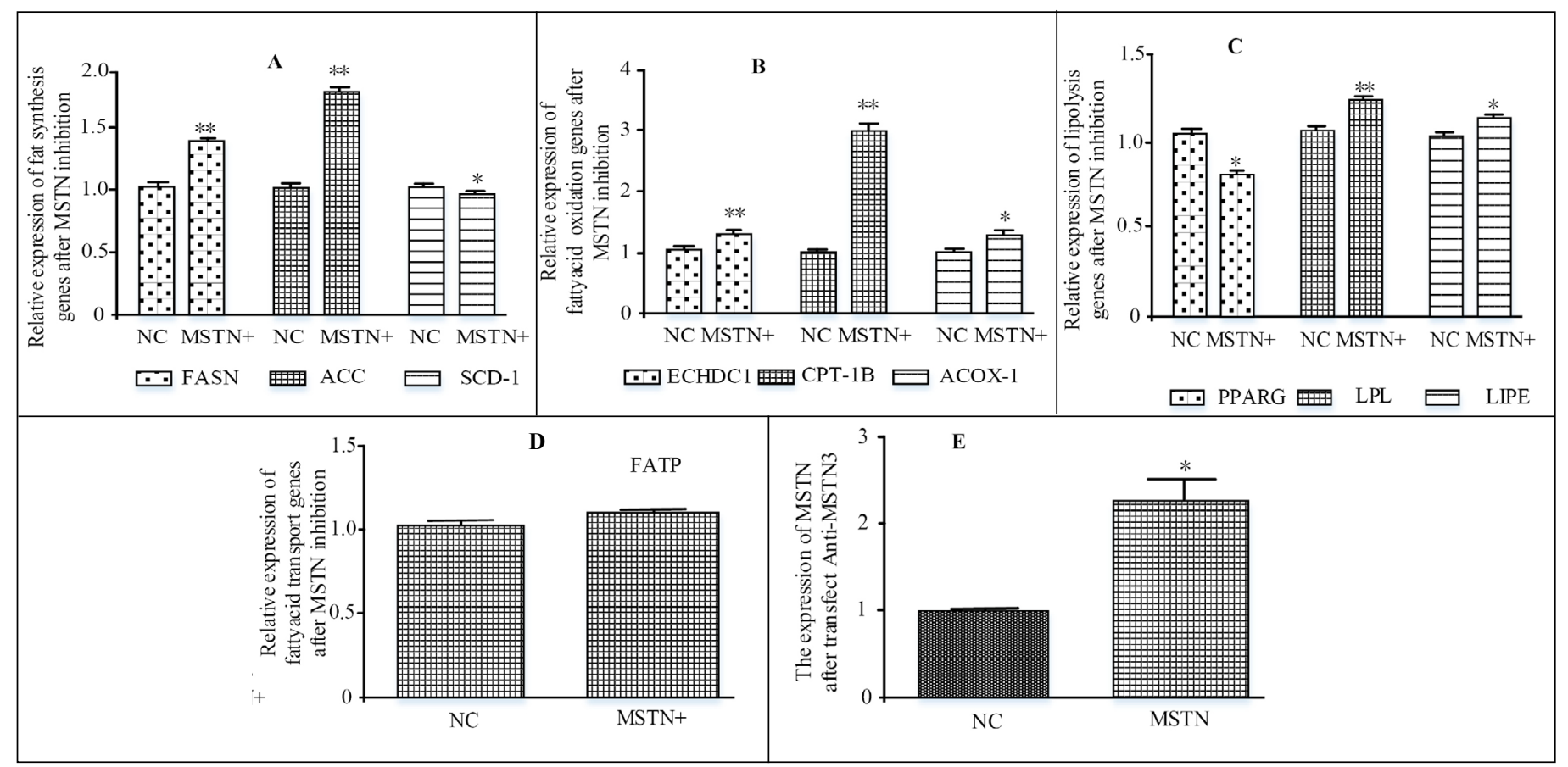

Figure 5. Expression of fat related genes after MSTN overexpression in bovine muscle satellite cells.

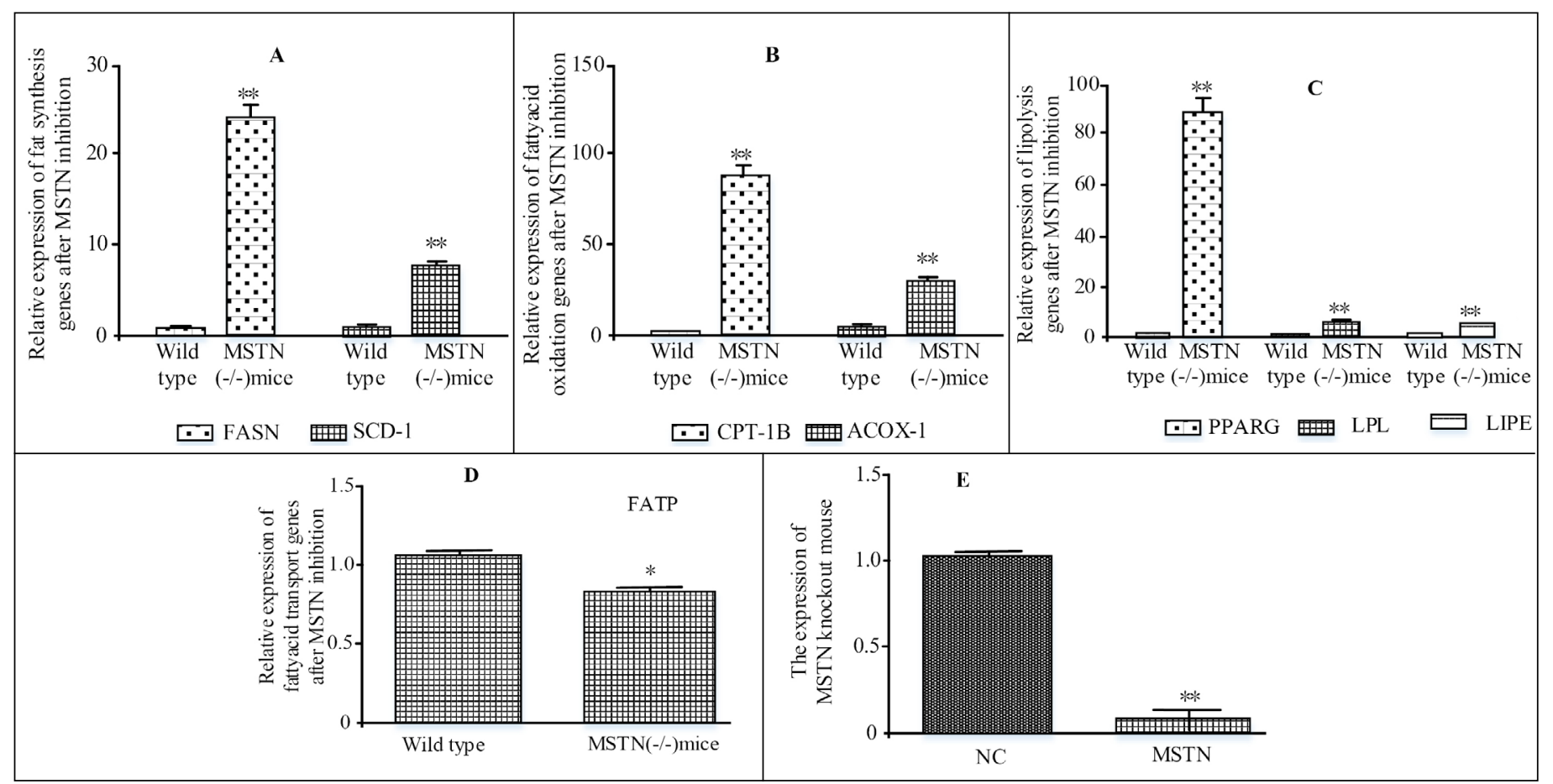

Figure 6. Muscle tissues of MSTN knockdown mice were taken to detect the expression of fat related genes.

were significantly increased; in Fig. B, the expression levels of cpti-b (89.15, $P<0.01)$ and acox-1 (30.76, $P<0.01)$ were significantly increased in Fig. a; PPARG was shown in Fig. CThe results showed that the expression levels of Lipofectamine (87.84, P < 0.01), lip $(6.33, P<0.05)$ and LPL $(6.24, P<0.01)$ were significantly increased; the expression of fat transport gene in Figure D was decreased with significant difference; the expression of MSTN $(0.25$, $P<0.01$ ) was decreased in muscle tissue of MSTN knockdown mice, and the changes were significant. On the whole, the oxidative decomposition degree of fat (220.33) was stronger than that of fat synthesis (31.36).

\section{CONCLUSION}

With the popularization of gene chip technology, MSTN has entered a new field to coordinate the proliferation and differentiation of body fat and skeletal muscle cells and the balance of energy metabolism. In this study, MSTN was used to study the effects of MSTN on skeletal muscle cells, fat and energy metabolism. The results showed that the expression of Cdc42, bnip2 and p38 genes could be promoted by inhibiting the expression of MSTN gene and directly knocking out MSTN gene, thus affecting the division, growth and differentiation of myoblasts, thus regulating the development of skeletal muscle After $\mathrm{N}$ gene, the expression of fat related genes in corresponding cells showed a trend from fat synthesis to fat decomposition; when MSTN gene was overexpressed, fat related genes also showed a trend from fat synthesis to fat decomposition direction; it indicated that both MSTN gene knockout and overexpression would affect lipid accumulation. When MSTN gene knockdown, the expression of cpti-b 
gene and PPARG gene in the corresponding cells was significantly up-regulated; after MSTN overexpression, the relative expression of PPARG gene was significantly decreased; it indicated that the decrease of fat may be directly affected by cpti-b gene and PPARG gene. Although the mechanism of MSTN activation in skeletal muscle has not been studied in detail, we should focus on the mechanism of MSTN activation in skeletal muscle.

\section{ACKNOWLEDGEMENTS}

This work was supported by Shaanxi Natural science project: Research on the effect of MSTN on Lipid metabolism and its mechanism in skeletal muscle cells under electrical stimulation, item number: 2020JM-174.

All authors declare no potential conflict of interest related to this articlee

AUTHORS' CONTRIBUTIONS: The author has completed the writing of the article or the critical review of its knowledge content. This paper can be used as the final draft of the manuscript. Every author has made an important contribution to this manuscript. Rihua Cong: writing and execution. Qijun Ren: data analysis.

\section{REFERENCES}

1. Pulliam JVK, XuZ, Ford GD. Computational identification of conserved transcription factor binding sites upstream of genes induced in rat brain by transient focal ischemic stroke. Brain Research. 2015;1495(3):76-85.

2. Li C, Ding $X$, Liu Z. Rapid identification of Candida spp. frequently involved in invasive mycoses by using flow-through hybridization and Gene Chip (FHGC) technology. Journal of Microbiological Methods. 2017; 132(12):160-165.

3. GY Han, Z Xu, QS Li, et al. Detection of hereditary hearing loss gene by DNA microarray. Eur Rev Med Pharmacol. 2017; 21(16):3538-3542.

4. Fan DJ, Li CY, Chen J, et al. Correlation between CYP2C19 Gene Polymorphism and Elderly Cerebral Infarction. Zhongguo yi xue ke xue yuan xue bao. Acta Academiae Medicinae Sinicae. 2018; 40(6):765-768.
5. Gu Hao, Cao Yong, Qiu Bin, et al. Establishment and phenotypic analysis of an Mstn knockout rat. Biochemical and Biophysical Research Communications. 2016, 477(1):115-122

6. Wright S, Wilde S. Supporting student transitions 14-19. Approaches to teaching and learning. By John Bostock and Jane Wood. Genetics Research. 2016; 84(3):161-73.

7. Kang JD, Kim S, Zhu HY, et al. Generation of cloned adult muscular pigs withmyostatin gene mutation by genetic engineering. RSC Advances. 2017; 7(21):12541-12549.

8. Chen R, Wen C, Cheng Y, et al. Effects of dietary supplementation with betaine on muscle growth, muscle amino acid contents and meat quality in Cherry Valley ducks. Journal of Animal Physiology and Animal Nutrition. 2019; 103(4):1050-1059. 